\title{
Consequences of psychoactive substance use: a comparative study of two services in Brazil and Portugal
}

\author{
Consequências do consumo de substâncias psicoativas: estudo comparativo entre \\ dois serviços do Brasil e Portugal \\ Consecuencias del consumo de sustancias psicoactivas: estudio comparativo entre \\ dos servicios de Brasil y Portugal
}

How to cite this article:

Boska GA, Seabra PRC, Oliveira MAF, Fernandes IFAL, Claro HG, Sequeira RMR. Consequences of psychoactive substance use: a comparative study of two services in Brazil and Portugal. Rev Esc Enferm USP. 2021;55:e20210138. DOI: https://doi.org/10.1590/1980-220X-REEUSP-2021-0138

\section{Gabriella de Andrade Boska ${ }^{1}$ \\ Paulo Rosário Carvalho Seabra ${ }^{2}$ \\ Márcia Aparecida Ferreira de Oliveira ${ }^{3}$ \\ D Ivan Filipe de Almeida Lopes Fernandes ${ }^{4}$ \\ D Heloísa Garcia Claro ${ }^{5}$ \\ Rui Manuel Russo Sequeira ${ }^{6}$}

${ }^{1}$ Universidade de São Paulo, Escola de

Enfermagem, Grupo de Estudos em Álcool e outras Drogas, São Paulo, SP, Brazil.

${ }^{2}$ Escola Superior de Enfermagem de Lisboa, Lisboa, Portugal.

${ }^{3}$ Universidade de São Paulo, Escola de Enfermagem, Departamento de Enfermagem Materno Infantil e Psiquiátrica, São Paulo, SP, Brazil.

${ }^{4}$ Universidade Federal do ABC, Centro de Engenharia, Modelagem e Ciências Sociais Aplicadas, Santo André, SP, Brazil.

${ }^{5}$ Universidade Estadual de Campinas, Faculdade de Enfermagem, Campinas, SP, Brazil.

${ }^{6}$ Equipe Técnica Especializada de Tratamento do Barreiro, Lisboa, Portugal.

\section{ABSTRACT}

Objective: To compare the consequences of psychoactive substance use among users of mental health services in Brazil and Portugal. Method: Cross-sectional, comparative, quantitative study, carried out with 362 users of two specialized treatment services in the cities of São Paulo $(n=200)$ and Lisbon $(n=162)$. Data collected in 2019 through the application of the Substance Addiction Consequences scale. A descriptive analysis and ordinary least squares and logistic regressions were performed. Results: All dimensions assessed by the scale were more severe for Brazilian users, with a difference for the physical domain and cognitive skills $(p<0.01)$. Brazilian participants were more likely to consume cocaine $(\mathrm{p}<0.01)$ and have psychosis $(\mathrm{p}=0.02)$ and Portuguese participants to have hepatitis $(p<0.01)$, personality disorders $(p<0.01)$, use benzodiazepines $(\mathrm{p}<0.01)$ and tobacco $(\mathrm{p}<0.01)$, and receive pharmacological support $(p<0.01)$. Conclusion: It was found that Brazilian users have more serious consequences related to substance use, and Portuguese users have more comorbidities and exposure to risky consumption. It emerges that Portuguese responses minimize the consequences severity.

\section{DESCRIPTORS}

Substance-Related Disorders; Comparative Study; Brazil; Portugal; Consequence Analysis. 


\section{INTRODUCTION}

Addressing the consequences of psychoactive substance (PAS) use is one of the global priorities for public health, mental health, and sustainable development. This consensualization is undertaken by many international entities, as the impact of these consequences has similar characteristics in several countries, and results in an increase in morbidity and mortality rates, reduced quality of life, as well as association with numerous other problems, such as those of a social nature ${ }^{(1-2)}$.

Brazil and Portugal have a historical relationship, resulting in similarities in language and culture; however, they differ in economic and social development, size, population composition, economic resources, disease burden, and approaches to the use of PAS. Both countries have public health systems, based on the guarantee of and right for universal access to health, according to principles of integrality and decentralization ${ }^{(3)}$; despite this proximity, each one operates with opposing public policies and programs of criminalization (Brazil) and decriminalization of consumption (Portugal), which contrast relying on the social understanding of substance users in each country ${ }^{(4-5)}$.

Regarding PAS consumption, the Brazilian population can be characterized by early onset, on average at 16 years of age, and has a more expressive rate of dependence of the general population on alcohol (1.5\%), followed by other drugs ( $0.8 \%)$. Approximately $1.1 \%$ of Brazilians receive some type of treatment, mainly in therapeutic communities $(0.61 \%)$, for the use of crack, a highly visible substance in the country ${ }^{(6)}$. In Portugal, consumption is later started, on average at 18 years of age, and the dependency rate among the general population is $0.8 \%$ for alcohol, $0.7 \%$ for marijuana, and $0.5 \%$ for opiates (with $0.2 \%$ of injection use) ${ }^{(7)}$. Approximately $0.27 \%$ of the Portuguese population receives treatment, mainly in outpatient clinics in the public network through drug support programs for alcohol and maintenance with methadone or buprenorphine for heroin users ${ }^{(8)}$.

Health response for people with problems arising from the use of PAS, similar in both contexts, is organized mainly in public specialized treatment units, with effective dispersion throughout the country. In general, they presuppose outpatient, psychosocial and community care, detoxification in a full-time care scheme, if necessary, and outreach responses such as street teams (which in Portugal come mostly from non-governmental organizations) that implement risk reduction and damage minimization actions ${ }^{(6-7)}$. In Brazil, specialized services make up the Psychosocial Care Network (RAPS), as a psychosocial care device. In Portugal, they are currently integrated into the primary health care network and cover opioid maintenance programs. It should be noted that, in both countries, social support for this population has varied over the years and is marked by political and economic cycles that reflect in greater or lesser support ${ }^{(6,9)}$.

In the different paths taken by the two countries in the fight against the problem of PAS use, which currently involves the populations' health, rights, and safety, new and similar challenges are being experienced in both settings regarding the reduction of resources for advances in the area, and weakening of legislation, which demands updates to follow and sustain the international guidelines of more humanized care policies for people who use drugs $s^{(5,10-11)}$. The need for greater scientific in-depth studies, both in Brazil and in Portugal, on the specificities of PAS use, can benefit from a look at the knowledge of the consequences that this consumption brings to the lives of users in these two countries, which, comparatively speaking, is still general. This reality can be studied taking into account the same concept and the political and care aspects of both settings, and its potential to respond to the problem, so that the experiences offer useful elements to support new studies and practices ${ }^{(5)}$.

In health studies, regarding the assessment of the results of care provided or characterization of the health status, one can resort to the use of the Nursing Outcome Classification (NOC), which provides a set of health outcomes aimed at various issues ${ }^{(12)}$. This taxonomy defines consequences of substance dependence as: "the impairment of health status and social function resulting from the use of alcohol and other drugs"(12), a construct that can be measured by the Substance Addiction Consequences (SAC) scale. This instrument was developed and validated by Seabra et al. in 2018 and derives from NOC results. It assesses the multidimensionality of the phenomenon of consequences of substance use in four subscales and can be applied by the multidisciplinary team, as it considers the user's own perception of their consumption and sets psychiatric diagnosis aside as a determinant of care, reinforcing the problem complexity and extent ${ }^{(13)}$.

The SAC scale has been used in the context of specialized treatment services for PAS use in Portugal to assess the severity of consequences and plan care, as well as to support the identification of self-management factors of these consequences by users ${ }^{(14)}$. It was recently culturally adapted and validated for use in Brazil with the quality required to be used by teams of community services for treating alcohol and other drugs abuse ${ }^{(15)}$. Therefore, records on its use have not yet been documented.

In this regard, the aim of this study was to compare the consequences of PAS use among users of two mental health services in Brazil and Portugal.

\section{METHOD}

\section{Design of Study}

This is a cross-sectional, comparative, quantitative study, part of the matrix project "Results of treatment for alcohol and other drugs in Psychosocial Care Centers modality III: cohort study". It was conducted by researchers from Brazil and Portugal, to compare the similarities and differences in the consequences of PAS use within populations attended at two specialized treatment services in both countries.

\section{LOCAL}

In Brazil, it was carried out in a Psychosocial Care Center for Alcohol and other Drugs III (CAPS AD III), in the city of São Paulo, and in Portugal, in a Specialized Technical Treatment Team (ETET), in the metropolitan 
area of Lisbon. Both CAPS and ETET are community and specialized services providing outpatient and multidisciplinary care for people with problems related to the PAS use.

CAPS AD III, unlike ETET, provides for full reception (24h) and detoxification, when necessary, and in 2019 it had around 550 active medical records. It is a reference in mental health care for people in the central region of São Paulo; thus, it has a more structured health and social assistance network for the population in a vulnerable condition. ETET, also located in one of the most vulnerable territories in Lisbon, in 2018, had 820 active records and 579 users in a drug support program (methadone, buprenorphine or aversive medication for alcohol dependence) and followed in nursing consultations.

\section{Sampling and Data Collection}

The study included 362 users undergoing treatment in specialized services, 200 in CAPS AD III in Brazil and 162 in ETET in Portugal. Participants were selected in a convenience sampling according to the following inclusion criteria: being in treatment at one of the research services (CAPS AD III Brazil and ETET Portugal), being 18 years old or older, and being able to answer the survey regarding the criteria of psychic organization and physical condition. Those who did not fully respond to the data collection instrument were excluded. In CAPS AD III in Brazil, 231 users were addressed, 19 did not accept to participate, and $12 \mathrm{did}$ not finish the instrument filling reporting physical and/or mental fatigue. At the ETET in Portugal, all users who were attended in the individual nursing consultation during the study period ( $\mathrm{n}=162$ ) agreed to participate.

In Brazil, data were collected exclusively by a research team allocated to CAPS AD III, consisting of three research nurses working in the field of alcohol and other drugs; in Portugal, by two ETET nurses during the nursing consultation. All those involved underwent training with the authors of the original SAC scale to conduct data collection.

Data collection was simultaneously performed in both countries, from February to December 2019, and was carried out through the use of an instrument containing a sociodemographic questionnaire (identification issues, age, sex, race, marital status, support network, income, employment status, housing conditions), questionnaire on health conditions (physical and psychiatric comorbidities) and PAS use (type of substance used and route of use), and the SAC scale, in its adapted version for each country ${ }^{(13,15)}$, which measured the consequences of consumption. The instrument was adapted to cover each research setting; thus, the sociodemographic questionnaire was slightly different for each country, with data on race and housing conditions not being collected in Portugal.

The SAC scale has 16 items and four domains corresponding to subscales of the instrument itself with a variable number of items (which is why the observable value is always adjusted to the number of items): 1 - psychological and familial (4 items); 2 - physical and cognitive skills (5 items); 3 - self-care (4 items); and 4 - economic and occupational (3 items). They are assessed through likert-like measures ranging from very severe consequence (1) to no consequence (5). As used in the original study, 48 points were established as a reference value to assess the consequences severity, which represents $50 \%$ of the total score resulting from the sum of all items. Scores close to the minimum correspond to more severe individuals $(<48)$ and scores closer to the maximum correspond to less severe individuals $(>=48)^{(13)}$.

\section{Data Analysis and Treatment}

Data were coded and entered into the software STATA, with descriptive analysis to assign absolute and relative frequencies and characterize the consequences of consumption by the scale domains and ordinary and logistic least squares regressions to verify substantive and statistical differences in the independent variable: country of origin (Brazil $=0$ and Portugal $=1$ ).

For response variables, we selected the scores of the SAC subscales and the full scale, measured by aggregation and analyzed by ordinary least squares regressions. We also analyzed the difference between Brazilian and Portuguese participants in terms of the existence of a diagnosis of depression, diabetes, hepatitis, hypertension, HIV, psychosis, reference on the SAC scale, bipolar affective disorder, personality disorder, tuberculosis, alcohol consumption, benzodiazepines, cocaine/crack, marijuana, tobacco, and drug support. All these variables are binary; therefore, they are analyzed using logistic regressions.

To reduce possible confounding effects in the model, we selected as control variables: receiving social benefits, age, number of children, household/with whom they live, marital status, sex, and employment status. The analysis of these variables is available as complementary material.

When an association is found between the predictor variable (country) and the response variables, we can infer the degree of association regardless of the control variables. We used 95\% confidence intervals and considered $\mathrm{p}$ value < or $=0.05$ for signaling in the tables. To standardize data, the estimated coefficient for Portugal will be presented, with the results in Brazil being a comparison category.

\section{Ethical Aspects}

Both studies were ethically approved by competent agencies in each country. In Brazil, the project was approved in 2019 by the Research Ethics Committees of the Nursing School of Universidade de São Paulo and the Municipal Health Department of São Paulo (3.167.092/2019 and 3.248.662/2019), in accordance with Resolution n. 466/2012, of the National Health Council. In Portugal, it was approved by the Health Ethics Committee of the Regional Health Administration of Lisbon and Vale do Tejo (111/CES/ INV/2018). All participants signed an informed consent form.

\section{RESULTS}

\section{Socioeconomic Characteristics, Health Conditions and Pas Use}

The Brazilian participants had a mean age of 44 years, had a minimum support network, having as household/ people living with them an average of one person and no children; in addition, 154 (77\%) were homeless at the time 
of the research. For Portuguese participants, the mean age rises to 47 years, the support network also increases to two people with an average of one child. In Portugal, users were not asked about housing situation as this problem was not identified in this setting.

As for PAS use, the difference between the use of cocaine/crack (40\% higher in Brazil) and opiates (18\% higher in Portugal) is highlighted. The other characteristics compared between countries are described in Table 1 .

\section{Consequences of PAs Use}

In the description of the domains of the SAC scale shown in Table 2, in all dimensions consequences severity is greater in the Brazilian sample. In the comparative analysis, differences were identified between countries in the total SAC scale and in the domain 2-Physical and cognitive abilities (cognitive and memory difficulties, inability to make decisions and take care of the house and reduced physical

Table 1 - Socioeconomic, health, and psychoactive substance use characteristics of the participants - São Paulo, SP, Brazil, Lisbon, Portugal, 2019.

\begin{tabular}{|c|c|c|c|c|}
\hline \multicolumn{2}{|c|}{ Participants characterization } & Brazil & & Total \\
\hline \multirow{2}{*}{ Sex } & Female & $34(17)$ & $38(23.4)$ & $72(19.8)$ \\
\hline & Male & $166(83)$ & $124(76.5)$ & $290(80.2)$ \\
\hline \multirow{2}{*}{ Marital status } & With partner & $23(11.5)$ & $48(29.6)$ & $71(19.5)$ \\
\hline & No partner & $177(88.5)$ & $114(70.2)$ & $291(80.2)$ \\
\hline \multirow{3}{*}{ Employment status } & Jobless & $134(67)$ & $90(55.5)$ & $224(61.8)$ \\
\hline & Informal job & $60(30)$ & $14(8.6)$ & $74(20.4)$ \\
\hline & Formal work & $6(3)$ & $58(35.8)$ & $64(17.6)$ \\
\hline Social benefits & Yes & $123(61.5)$ & $44(27.1)$ & $167(46.1)$ \\
\hline \multirow{5}{*}{ Physical comorbidities } & Hypertension & $37(18.5)$ & $24(14.8)$ & $61(16.8)$ \\
\hline & Diabetes & $14(7)$ & $23(14.2)$ & $37(10.2)$ \\
\hline & HIV/AIDS $^{+}$ & $20(10)$ & $15(9.2)$ & $35(9.6)$ \\
\hline & Tuberculosis & $19(9.5)$ & $19(11.7)$ & 38 (10.5) \\
\hline & Hepatitis & $6(3)$ & $79(48.7)$ & $85(23.4)$ \\
\hline \multirow{3}{*}{ Psychiatric comorbidities } & Mood disorder & $88(44)$ & $49(30.2)$ & $137(37.7)$ \\
\hline & Personality disorder & $9(4.5)$ & $21(12.9)$ & $30(8.2)$ \\
\hline & Psychosis & $27(13.5)$ & $6(3.7)$ & $33(9.1)$ \\
\hline \multirow{6}{*}{ Psychoactive substance used } & Alcohol & $165(82.5)$ & $132(81.4)$ & $297(82)$ \\
\hline & Tobacco & $136(68)$ & $129(79.6)$ & $265(73.2)$ \\
\hline & Marihuana & $90(45)$ & $43(26.5)$ & $133(36.7)$ \\
\hline & Cocaine/crack & $123(61.5)$ & $33(20.3)$ & $156(43)$ \\
\hline & Benzodiazepines & $7(3.5)$ & $30(18.5)$ & $37(10.2)$ \\
\hline & Opiates & $5(2.5)$ & $33(20.4)$ & 49 (22.9) \\
\hline Consumption route & Intravenous & $5(2.5)$ & $5(3.1)$ & $10(2.7)$ \\
\hline Pharmacological support* & Yes & $142(71)$ & $158(97.5)$ & $300(82.8)$ \\
\hline
\end{tabular}

*Pharmacological support: Brazil = any medication prescribed by the service; Portugal = opioid replacement drug therapy; ${ }^{\dagger} \mathrm{HIV} / \mathrm{AIDS}=\mathrm{Human}$ Immunodeficiency Virus. $\mathrm{n}$ Brazil $=200 ; \mathrm{n}$ Portugal $=162 ; \mathrm{n}$ Total $=362$.

Table 2 - Substance addiction consequences among scale domains with country as independent variable - São Paulo, SP, Brazil, Lisbon, Portugal, 2019.

\begin{tabular}{cccccc}
\hline SAC scale domains* & $\begin{array}{c}\text { Brazil } \\
\text { Average }\left(\mathbf{S D}^{+}\right)\end{array}$ & $\begin{array}{c}\text { Portugal } \\
\text { Mean }\left(\mathrm{SD}^{+}\right)\end{array}$ & Difference (SE) & p-value & \multirow{2}{*}{$\mathbf{R}^{2}$} \\
\hline 1-Psychological and familial & $2.41(0.938)$ & $2.74(1.072)$ & $0.204(0.129)$ & 0.11 & 0.10 \\
\hline 2-Physical and cognitive skills & $2.91(0.949)$ & $3.73(0.922)$ & $0.653(0.123)$ & 0.00 & 0.20 \\
\hline 3-Self care & $3.30(0.753)$ & $3.40(0.910)$ & $-0.048(0.108)$ & 0.66 & 0.05 \\
\hline 4-Economic and occupational & $2.18(0.981)$ & $2.76(1.538)$ & $-0.071(0.150)$ & 0.63 & 0.26 \\
\hline Total & $43.97(9.775)$ & $51.59(12.666)$ & $3.675(1.420)$ & 0.01 & 0.20 \\
\hline
\end{tabular}

*SAC = Substance Addiction Consequences; ${ }^{+} \mathrm{SD}=$ Standard deviation; ${ }^{\star} \mathrm{SE}=$ Standard error (Ordinary Least Squares Regression Coefficient for the independent variable of interest). $\mathrm{n}$ Brazil $=200 ; \mathrm{n}$ Portugal $=162$. 
Table 3 - Participants' health and substance use characteristics and SAC* scale with country as independent variable - São Paulo, SP, Brazil, Lisbon, Portugal, 2019.

\begin{tabular}{|c|c|c|c|}
\hline Response variables & $\begin{array}{c}\text { Estimated } \\
\text { coefficient }\left(\mathrm{OR}^{+}\right)\end{array}$ & $\begin{array}{l}\text { Standard } \\
\text { error }\end{array}$ & p-value \\
\hline Depression & 0.739 & 0.217 & 0.30 \\
\hline Diabetes & 2.204 & 1.089 & 0.11 \\
\hline Hepatitis & 63.657 & 35.056 & 0.00 \\
\hline Hypertension & 0.847 & 0.331 & 0.67 \\
\hline $\mathrm{HIV}^{\ddagger}$ & 0.971 & 0.470 & 0.95 \\
\hline Psychosis & 0.263 & 0.151 & 0.02 \\
\hline SAC scale reference* $(48)$ & 1.961 & 0.557 & 0.01 \\
\hline Bipolar affective disorder & 0.984 & 0.844 & 0.98 \\
\hline Personality disorder & 11.403 & 6.596 & 0.00 \\
\hline Tuberculosis & 1.780 & 0.831 & 0.21 \\
\hline Alcohol consumption & 1.211 & 0.507 & 0.64 \\
\hline $\begin{array}{l}\text { Consumption of } \\
\text { benzodiazepines }\end{array}$ & 8.586 & 4.424 & 0.00 \\
\hline $\begin{array}{c}\text { Cocaine/crack } \\
\text { consumption }\end{array}$ & 0.198 & 0.062 & 0.00 \\
\hline Marijuana use & 0.782 & 0.226 & 0.39 \\
\hline Pharmacological support & 53.529 & 56.956 & 0.00 \\
\hline Tobacco use & 3.691 & 1.310 & 0.00 \\
\hline
\end{tabular}

*SAC = Substance Addiction Consequences; ${ }^{+} \mathrm{OR}=$ odds ratio (odds ratio estimated by logistic regression for the independent variable of interest); ${ }^{\ddagger}$ HIV/AIDS = Human Immunodeficiency Virus. $\mathrm{n}=362$

activity), with the population of Brazil showing more severe consequences than that from Portugal. In the analysis of the difference, positive coefficients indicate a less serious situation for Portuguese users, and negative coefficients for Brazilian users.

In the logistic regression presented in Table 3, differences were identified in the chances of Portuguese participants presenting more hepatitis (63.6), personality disorders (11.4), use of benzodiazepines (8.5) and tobacco (3.6), and receipt of pharmacological support (53.5). Brazilians, in their turn, are more likely to use cocaine (0.2) and have psychosis $(0.3)$, as well as to have more serious consequences related to PAS use (1.9).

\section{DISCUSSION}

When comparing the characteristics of the participants and the consequences of PAS use, we found that users from Portugal have a higher risk consumption, as well as more physical and psychiatric comorbidities; however, users in Brazil manifest more consequences related to consumption and greater severity in all dimensions assessed by the SAC scale. Considering the similarities between health care systems and models in the two countries, this finding suggests the influence of public policies and consequent Portuguese responses, which apparently reduce the severity of the consequences of consumption at the biopsychosocial level.

Portugal has a structured policy focused on harm reduction with increased access to different types of care, such as opioid maintenance therapies and assisted consumption units; it also promotes concrete social reintegration opportunities for people who use drugs, such as "Housing First" for homeless people, which has not yet occurred in Brazil ${ }^{(5)}$.

The policy of decriminalizing the consumption of all substances, adopted in Portugal, allowed change in the profile of users assisted in treatment services with a reduction in social vulnerability, opportunities for inclusion in the community through work and housing, given the recognition of the use of PAS as a health problem ${ }^{(16)}$. This difference is evident in the socioeconomic characteristics of the participants in this research, as users assisted in the service in Brazil have little access to housing, formal work and income, in addition to a minimal support network, variables directly associated with the severity of PAS use ${ }^{(5)}$.

When comparing the dimensions of the SAC scale, the two subscales with the worst results $(1-$ Psychological and familial and 4 - Economic and occupational) are similar in both services, suggesting that the impact of substance use assumes approximate severity indicators, datum that corroborates a global analysis of the damage caused by situations of problematic use of PAS, namely when in the pattern of dependence ${ }^{(1)}$.

Regarding subscale 2 (Physical and cognitive skills), it had the best averages for both service users in Brazil and Portugal; however, the regression showed the only difference between countries. This result can be explained by the singularities of the Brazilian participants, with regard to social determinants of health (marginality, poverty, exclusion, stigma, and social inequality) and by the rituals of cocaine/ crack use (consecutive days of use and absence of others activities of daily living) ${ }^{(4,17)}$, factors that can impair the functionality and reduction of individuals' physical activity, measured by this domain.

In addition, the greater severity of the total consequences measured by the SAC scale among Brazilian users was confirmed in logistic regression, with a $1.9 \%$ higher chance of occurring.

Comparing the other characteristics of users seen in the two services, we found differences in the type of substance consumed. Brazilians are more likely to use cocaine/crack, while the Portuguese are more likely to use benzodiazepines and tobacco.

It is known that the use of cocaine/crack is more prevalent in Brazil and especially in the population studied, due to the dissemination and access to this substance in vulnerable settings, as well as that the prevalence of tobacco use, despite its legality, has been decreasing over time, probably associated with measures to control the supply, with the prohibition of advertisements about the product, the prohibition of smoking indoors, and the increase in taxes for the consumer ${ }^{(6)}$. Unlike the Portuguese context, the drug of choice for $71 \%$ of subjects undergoing treatment in public clinics, as is the case in this study, is heroin, and the old and cultural behavior of tobacco use remains with no major restrictions ${ }^{(8)}$.

Regarding the consumption of benzodiazepines, this was reported by 7 (3.5\%) Brazilian participants and 
30 Portuguese (18.5\%) ones. A report on consumption patterns and problems related to drug use in Portugal showed that $37.3 \%$ of the population with problems resulting from the use of PAS take over-the-counter hypnotics and sedatives $^{(8)}$, datum that helps to explain the greater chance found in this study of use of these psychoactive agents, in relation to Brazil. Another study evidenced the common association between the use of heroin and benzodiazepines, due to the similar sedative effect, and points to an expected relationship of dependence on these two substances ${ }^{(18)}$, which in Brazil does not seem to be a relevant association for the consumption profile of users studied. Another issue that may explain the data is the ease of access to benzodiazepines in Portugal ${ }^{(7)}$.

Another finding with a strong difference in the comparison line was the pharmacological support. Users undergoing treatment at the service in Portugal were 53.5\% more likely to receive pharmacological support than in Brazil and this data is directly associated with drug replacement therapies available in the Portuguese public network, as a possibility of treatment for opioid dependence with the agonist methadone. This issue is at the same time a difference for the SAC scale, as $97.5 \%$ of the Portuguese at the time of the research were in opioid substitution programs and only 5 (3.1\%) maintained injectable use, which suggests that these programs reduce the option for intravenous consumption significantly, thus reducing its damage ${ }^{(13)}$.

Opioid replacement therapy in Portugal is yet another example of expanded care that reduces the consequences of PAS use along the lines of decriminalization, considered a global model of effective response in health ${ }^{(4)}$. In $2017,16,888$ people were registered in replacement therapies ${ }^{(8)}$. These programs work from the perspective of harm reduction with populations that are more excluded, with a low threshold of demand, thus breaking accessibility barriers, focusing their actions on retaining users, and being flexible towards the choice of type and time of treatment; in addition, they present increasing evidence of better results when compared to proposals with a high demand threshold ${ }^{(19)}$.

Although opiate use is not a central problem in Brazil, $71 \%$ of participants reported receiving pharmacological support at the service studied. Medicalization centered in the groups of anxiolytics, antidepressants, and antipsychotics, indicated to contain symptoms and signs of use and/or withdrawal from other PAS, is identified by a study as one of the central elements of treatment in CAPS AD, and enhances the controversy between prolongation of the dependency relationship when exchanging one substance (illicit) for another (prescribed), not naming it as a possible replacement therapy ${ }^{(20)}$. Some authors argue that the traditional biomedical model, based on withdrawal, can be one of the main ways of medicalizing the use of $\mathrm{PAS}^{(21)}$.

As for physical and mental health problems, we detected different comorbidities in each context studied. Brazilian users were more likely to have psychosis and Portuguese users, personality disorder and hepatitis.
There is a proven bidirectional association between the psychotic experience and substance use. Just as it is linked, in order of prevalence, to alcohol, tobacco, marijuana and cocaine consumption, people diagnosed with psychosis use three to five times more stimulants than the general population. However, in all cases, it is also necessary to consider the personal, social, and environmental factors involved in this association, especially among marginalized populations ${ }^{(22)}$. Social vulnerability and consumption of stimulants (cocaine/ crack) by Brazilian users may confirm the greater chances of psychosis in this population. Moreover, Portugal has rates of $0.5 \%$ for psychosis and $3.5 \%$ for personality disorders in the drug user population ${ }^{(23)}$; however, we found scarcity of investigations relating PAS use to psychiatric comorbidities identified as significant in this study.

The diagnosis of hepatitis was different for the Portuguese sample, being $63 \%$ more likely to occur. This datum corroborates national statistics. The overall seroprevalence of hepatitis $\mathrm{C}$ in Portugal is $67.6 \%, 94.2 \%$ in injection drug users, $81.5 \%$ in injection drug users admitted for treatment, and $75.6 \%$ in people using alcohol, populations considered at risk due to the characteristics favoring the spread of the infection $^{(8,24)}$.

Another factor that can be related to this data are the screening and treatment programs for hepatitis in Portugal. They focus on vulnerable populations, including PAS users, with coverage between $91 \%$ and $95 \%$ in public network units ${ }^{(25)}$. As the strategies seek to promote the diagnosis and provide mobile units with screening and treatment conditions for people who are often aversive, or do not have easy access to health care ${ }^{(22)}$, a hypothesis is formulated that the Portuguese participants have more knowledge about the diagnosis.

In Brazil, hepatitis is also considered a serious public health problem for people who use PAS, especially those on the street, due to the high rates of infection associated with vulnerability, risky sexual behavior, and sharing of objects for drug use (6.26). However, the prevalence of diagnosed cases nationwide is much lower than that reported in Portugal, ranging from $2.4 \%$ to $2.6 \%$ among crack users and reaching $5.8 \%$ for those undergoing treatment ${ }^{(26)}$, similar to that found in this study (3\%).

Some weaknesses are observed in the screening, diagnosis, and monitoring strategies of communicable diseases for the socially vulnerable population who use PAS in Brazil, especially the access barriers related to referrals to health services, a condition that prevents many people from knowing the diagnosis of hepatitis and having follow-up treatment. A study carried out with PAS users undergoing treatment at a CAPS AD identified that more than 50\% of the studied sample had never performed any diagnostic test for hepatitis ${ }^{(26)}$. On the other hand, this is a population profile that tends to classify physical and mental health between good and very good ${ }^{(27)}$, which may reflect on the results found.

Based on these findings, we reaffirm the need to consider, in the context of treatment services in Brazil, the consequences related to the consumption of non-injecting 
drugs that can be minimized with harm reduction strategies. An example is the sharing of straws, pipes, cans, and cups for cocaine/crack consumption as a risk factor that needs attention, since this behavior has been identified by national surveys among approximately $70 \%$ of users ${ }^{(6,18,27)}$ and it has already been confirmed by international studies, which also suggest the need for more consistent epidemiological research on this theme ${ }^{(27)}$.

The main limitation of this study was the difference in the instruments used in each country to collect data on the participants' socioeconomic characteristics. However, the use of the same scale to measure the consequences of substance use allowed a broad contextualization and discussion of the findings, meeting the objective. Secondly, we point out that the participants were sampled in two services, each located in one of the countries, so that the differences found in this study need to be confirmed with representative samples of the respective populations from Brazil and Portugal and with a greater number of services.

\section{CONCLUSION}

It appears that the consequences related to PAS use among users of the Brazilian and Portuguese services studied differ in type and severity, which are influenced by the singularities of each population and by the different responses of each service, guided by the country's public policies on drugs.

Brazilian users have more serious consequences related to PAS use in all dimensions assessed by the SAC scale, with significant differences that shall be considered in light of the social aspects of this population. Portuguese users are more likely to have health problems and risky behavior for consumption, but less serious consequences. Apparently, the divergence of actions between the services being compared impacted the severity of the consequences, with a better Portuguese response.

We assess the importance of subsidizing public decriminalization policies and strengthening comprehensive care programs for problems related to PAS consumption, as health needs go beyond the consequences of consumption. In addition, sponsoring harm reduction programs with a low requirement threshold can support Brazilian users to expand the possibilities of access to other care.

\section{SUPPLEMENTARY MATERIAL}

The following online material is available for this article https://data.scielo.org/dataset.xhtml?persistentId=doi\% 3A10.48331\%2Fscielodata.DAK7MG\&showIngestSucces $\mathrm{s}=$ true\&version $=\mathrm{DRAFT}$

\section{RESUMO}

Objetivo: Comparar as consequências do consumo de substâncias psicoativas entre usuários de serviços de saúde mental no Brasil e em Portugal. Método: Estudo transversal, comparativo, de natureza quantitativa, realizado com 362 usuários de dois serviços especializados de tratamento nas cidades de São Paulo $(n=200)$ e Lisboa $(n=162)$. Dados coletados em 2019 por meio da aplicação da escala Consequências da Dependência de Substâncias. Realizou-se análise descritiva e regressões de mínimos quadrados ordinários e logística. Resultados: Todas as dimensões avaliadas pela escala foram mais graves para os usuários brasileiros, com diferença para o domínio físico e habilidades cognitivas $(p<0,01)$. Destaca-se maior probabilidade dos participantes brasileiros para consumir cocaína ( $p<0,01)$ e ter psicose $(p=0,02)$ e dos portugueses ter hepatites $(p<0,01)$, transtorno de personalidade $(p<0,01)$, fazer uso de benzodiazepínicos $(p<0,01)$ e tabaco $(p<0,01)$ e receber suporte farmacológico $(p<0,01)$. Conclusão: Constatou-se que os usuários brasileiros apresentam consequências mais graves relacionadas ao consumo de substâncias e os portugueses, mais comorbidades e exposição a consumo de risco. Emerge que as respostas portuguesas minimizam a gravidade das consequências.

\section{DESCRITORES}

Transtornos Relacionados ao Uso de Substâncias; Estudo Comparativo; Brasil; Portugal; Análise de Consequências.

\section{RESUMEN}

Objetivo: Comparar las consecuencias del consumo de sustancias psicoactivas entre usuarios de servicios de salud mental en Brasil y Portugal. Método: Estudio transversal, comparativo de naturaleza cuantitativa, realizado con 362 usuarios de dos servicios especializados de tratamiento en las ciudades de Sao Paulo $(n=200)$ y Lisboa $(n=162)$. Datos recogidos en 2019 a través de la aplicación de la escala Consecuencias de la Dependencia de Sustancias. Se realizó análisis descriptivo y regresiones de mínimos cuadrados ordinarios y logística. Resultados: Todas las dimensiones calculadas por la escala fueron más graves para los usuarios brasileños, con diferencia para el dominio físico y habilidades cognitivas $(\mathrm{p}<0,01)$. Se destaca mayor probabilidad de que los participantes brasileños consuman cocaína $(p<0,01)$ y tengan psicosis $(p=0,02)$ y de que los portugueses tengan hepatitis $(p<0,01)$, trastorno de personalidad ( $p<0,01)$, utilicen benzodiacepinicos $(\mathrm{p}<0,01)$ y tabaco $(\mathrm{p}<0,01)$ y reciban soporte farmacológico $(\mathrm{p}<0,01)$. Conclusión: Se pudo constatar que los usuarios brasileños presentan consecuencias más graves relacionadas al consumo de sustancias y los portugueses, más comorbidades y exposición al consumo de riesgo. Se notó que las respuestas portuguesas minimizan la gravedad de las consecuencias.

\section{DESCRIPTORES}

Trastornos Relacionados con Sustancias; Estudio Comparativo; Brasil; Portugal; Análisis de las Consecuencias.

\section{REFERENCES}

1. United Nations. Office on Drugs and Crime. World Drug Report [Internet]. Vienna: UNODC; 2020 [cited 2021 Jan 20 ]. Available from: https://wdr.unodc.org/wdr2020/field/WDR20_Booklet_2.pdf.

2. Patel V, Saxena S, Lund C, Thrnicroft SG, Baingana F, Bolton P, et al. The Lancet Commission on global mental health and sustainable development. Lancet. 2018;392(10157):1553-98. DOI: http://dx.doi.org/10.1016/S0140-6736(18)31612-X.

3. Borysow IC, Conill EM, Furtado JP. Health care of people in homelessness: a comparative study of mobile units in Portugal, United States and Brazil. Cien Saude Colet 2017;22(3):879-90. DOI: http://dx.doi.org/10.1590/1413-81232017223.25822016. 
4. Mendes RO, Pacheco PG, Nunes JPCOV, Crespo PS, Cruz MS. Literature review on the implications of decriminalization for the care of drug users in Portugal and Brazil. Cien Saude Colet 2019;24:(3)395-406. DOI: http://dx.doi.org/10.1590/1413-81232018249.27472017.

5. Fraga P, Carvalho MC, organizadores. Drogas e sociedade: estudos comparados Brasil e Portugal. Rio de Janeiro: Letra Capital; 2019.

6. Bastos FIPM, Vasconcellos MTL, De Boni RB, Reis NB, Coutinho CFS, organizadores. III Levantamento Nacional sobre o uso de drogas pela população brasileira. Rio de Janeiro: FIOCRUZ/ICICT; 2017.

7. European Monitoring Centre for Drugs and Drug Addiction. Portugal, country Drug Report 2019 [Internet]. Portugal: EMCDDA; 2019 [cited 2021 Jan 23]. Available from: https://www.emcdda.europa.eu/system/files/publications/11331/portugal-cdr-2019_0.pdf.

8. Guerreiro C, Calado V. Padrões de Consumo e Problemas Ligados Uso de Drogas: Uma Análise Regional. Portugal: Serviço de Intervenção nos Comportamentos Aditivos e nas Dependências; 2019.

9. Gonçalves R, Lourenço A, Silva SN. A social cost perspective in the wake of the Portuguese strategy for the fight against drugs. Int J Drug Policy. 2015;26(2):199-209. DOI: http://dx.doi.org/10.1016/j.drugpo.2014.08.017

10. Brasil. Ministério da Saúde. Secretaria Executiva. Coordenação Nacional de DST e AIDS. A política do ministério da saúde para a atenção integral a usuários de álcool e outras drogas. $1^{\text {a }}$ ed. Brasília: Ministério da Saúde; 2003.

11. Portugal. Lei n. 30/2000 de 29 de novembro de 2000. Define o regime jurídico aplicável ao consumo de estupefacientes e substâncias psicotrópicas, bem como a protecção sanitária e social das pessoas que consomem tais substâncias sem prescrição médica. Diário da República, Lisboa, 29 nov. 2000. Seção 1, p. 1.

12. Moorhead S, Swanson E, Johnson M, Maas ML. Nursing outcomes classification (NOC): Measurement of Health Outcomes. St. Louis: Elsevier; 2018.

13. Seabra PRC, Amendoeira JJP, Sá LO, Capelas MLV. Clinical Validation of the Portuguese Version of "Substance Addiction Consequences" Derived from the Nursing Outcomes Classification. Issues Ment Health Nurs. 2018;39(9):779-85. DOI: http://dx.doi.org/10.1080/016 12840.2018.1462870.

14. Seabra P, Sequeira A, Filipe F, Amaral P, Simões A, Sequeira R. Substance Addiction Consequences: Outpatients Severity Indicators in a Medication-Based Program. Int J Ment Health Addict. 2021. DOI: https://doi.org/10.1007/s11469-021-00485-3.

15. Boska GA, Seabra PRC, Oliveira MAF, Claro HG, Fernandes IFAL. Validação da Escala Consequências da Dependência de Substâncias (CDS) para o uso no Brasil: Modelo Rasch. Revista Científica Internacional RevSALUS 2020[cited 2021 Feb 16];Suppl 2:140-1. Available from: https://revsalus.racslusofonia.org/wp-content/uploads/2020/09/RACS_Suplemento_n2_Setembro2020_AF.pdf.

16. Wiessing L, Ferri M, Běláčková V, Carrieri P, Friedman SR, Folch C, et al. Monitoring quality and coverage of harm reduction services for people who use drugs: a consensus study. Harm Reduct J. 2017;14(1):19. DOI: http://dx.doi.org/10.1186/s12954-017-0141-6.

17. Bard ND, Antunes B, Roos CM, Olschowsky A, Pinho LB. Stigma and prejudice: the experience of crack users. Rev Lat Am Enfermagem. 2016;24:e2680. DOI: http://dx.doi.org/10.1590/1518-8345.0852.2680.

18. Yamamoto T, Dargan PI, Dines A, Yates C, Heyerdahl F, Hovda KE, et al. Concurrent Use of Benzodiazepine by Heroin Users-What Are the Prevalence and the Risks Associated with This Pattern of Use? J Med Toxicol. 2019;15(1):4-11. DOI: http://dx.doi.org/10.1007/ s13181-018-0674-4.

19. Kourounis G, Richards BDW, Kyprianou E, Symeonidou E, Malliori M-M, Samartzis L. Opioid substitution therapy: Lowering the treatment thresholds. Drug Alcohol Depend. 2016;161:1-8. DOI: http://dx.doi.org/10.1016/j.drugalcdep.2015.12.021.

20. Vargas AFM, Campos MM. Entre o cuidado e a medicamentalização: os debates sobre "trocar uma droga por outra". Revista da Sociedade Brasileira de Sociologia. 2019;7(15):81-103. DOI: http://dx.doi.org/10.20336/rbs.441.

21. Silva MB, Delduque MC. The pathologization and criminalization of drug use: a socio-anthropological analysis of legislative proposals (2007-2010). Physis. 2015;25(1):231-50. DOI: https://doi.org/10.1590/S0103-73312015000100013.

22. Degenhardt L, Saha S, Lim CCW, Aguilar-Gaxiola S, Al-Hamzawi A, Alonso J, et al. The associations between psychotic experiences and substance use and substance use disorders: findings from the World Health Organization World Mental Health surveys. Addiction. 2018;113(5):924-34. DOI: http://dx.doi.org/10.1111/add.14145.

23. Perelman J, Chaves P, Almeida JMC, Matias MA. Reforming the Portuguese mental health system: an incentive-based approach. Int J Ment Health Syst. 2018;30(12):25. DOI: http://dx.doi.org/10.1186/s13033-018-0204-4.

24. Silva MJ, Pereira C, Loureiro R, Balsa C, Lopes P, Água-Doce I, et al. Hepatitis C in a Mobile Low-Threshold Methadone Program. Eur J Gastroenterol Hepatol. 2017;29(6):657-62. DOI: http://dx.doi.org/10.1097/MEG.0000000000000843.

25. Velosa J, Macedo G. Elimination of Hepatitis C in Portugal: An Urban Legend? GE Port J Gastroenterol. 2020;27(3):166-71. DOI: http:// dx.doi.org/10.1159/000505582.

26. Gusmão PP, Fernandes RFD, Rezende RC, Bonfim RS, Moura LR, Fernandes LC, et al. Prevalence of infections by the Hepatitis B and C virus in a population of drug users of Anápolis, Goiás. Revista Educação em Saúde. 2017;5(2):1-6. DOI: https://doi.org/10.29237/23589868.2017v5i2.p49-55.

27. Butler AJ, Rehm J, Fischer B. Health outcomes associated with crack-cocaine use: Systematic review and meta-analyses. Drug Alcohol Depend. 2017;180:401-16. DOI: http://dx.doi.org/10.1016/j.drugalcdep.2017.08.036.

Financial support

Coordenação de Aperfeiçoamento de Pessoal de Nível Superior - Brazil (CAPES) - Financing Code - 001. 